\title{
The Return : Intertextuality of the Reminiscing of Karelian Evacuees in Finland
}

\section{Savolainen, Ulla}

2017

Savolainen , U 2017 , ' The Return : Intertextuality of the Reminiscing of Karelian Evacuees

in Finland ' , Journal of American Folklore , vol. 130 , no. 516 , pp. 166-192 . https://doi.org/10.5406/jamerfolk.130.51

http://hdl.handle.net/10138/188835

https://doi.org/10.5406/jamerfolk.130.516.0166

publishedVersion

Downloaded from Helda, University of Helsinki institutional repository.

This is an electronic reprint of the original article.

This reprint may differ from the original in pagination and typographic detail.

Please cite the original version. 


\section{The Return: Intertextuality of the Reminiscing of Karelian Evacuees in Finland}

In this article, I examine the intertextuality of reminiscence writings of Karelian evacuees in Finland. The main topics of these writings are the two journeys of evacuation from the ceded Karelia to Finland, which writers experienced as children during and after the Second World War, and journeys back to the region of their childhood, which became possible after the collapse of the Soviet Union. In the case of negotiations surrounding spatiotemporal distance and the creation of bridges between the past and the present, I argue that intertextuality plays a crucial but somewhat underanalyzed role in reminiscing.

\section{Keywords}

Afs ethnographic thesaurus: Personal narratives, poetics, intertextuality, forced migration, travel

IN THIS ARTICLE, I EXAMINE THE INTERTEXTUALITY of reminiscence writings of Karelian evacuees who experienced forced displacement within their own country. These reminiscences were written by elderly persons evacuated from Karelia as children and produced in the context of a thematic collection campaign organized by the Finnish Karelian League in collaboration with the Finnish Literature Society's Folklore Archive in 2004. The reminiscences of Karelian evacuees deal with questions of place and belonging; they are about home, losing home, and returning home. The main topics of these writings concern the two evacuation journeys from the ceded Karelia to Finland, which writers experienced during the Second World War. In addition to memories of childhood evacuation journeys, these writings include descriptions of brief visits back to Russian Karelia following the collapse of the Soviet Union decades after the evacuations. In this article, I primarily concentrate my discussion on the topic of returning to the place of the childhood home decades later.

Despite a broad range of research connecting migration and diaspora, ${ }^{1}$ the linguistic and poetic dimensions of migrant narratives have not yet gained enough analytical attention (see BenEzer 2004:30). In this article, I offer a complementary perspective on migration and diaspora by turning the focus on the intertextual dimensions of diasporic reminiscing. I ask what kinds of poetic and narrative conventions illustrate

ULLA SAVOLAINEN is a postdoctoral researcher at the University of Helsinki, Finland 
stories of home written by Karelian evacuees. I pay special attention to how Karelian evacuees apply characteristics of idyllic, nostalgic, and documentary representation in their reminiscence writings. These specific generic frameworks express values relating to the time or setting that they describe, which explains why they are especially interesting in terms of reminiscences of migration or significant historical events. I suggest that these intertextual references are employed to create bridges for the gap between times and places in the past and the present, between childhood and the moment of writing. Furthermore, the writers utilize intertextual references to implicitly express controversial, ideological, or emotional views of the past and its relationship with the present. I also argue that analysis of the intertextuality of reminiscing enriches the methodological corpus of migration and diaspora studies as well as the research of different forms of life writing and oral history testimonies. Intertextual analysis has the potential to open new ways of understanding dimensions of human expression that are absent on the linguistic or thematic level of utterance but take place in a sociohistorical context between and across texts and genres. Thus, intertextual relations that also constitute genre should be recognized in order to penetrate the complexity of meanings included in reminiscence writings (see Briggs and Bauman 1992:132). I argue that such recognition advances understanding of the cultural competence of the writers as well as the discursive and textual contexts in which they and their writings belong. In addition, I analyze the relationship between written dialect and standard language use; in the case of the example I provide here, this reflects the dynamic cooperation of the above-mentioned generic frameworks in actions that are typical of the reminiscence writings of Karelian evacuees. The use of dialect is a characteristic poetic quality of evacuation journey writings in which negotiations of time as well as place, group, identity, and agency intertwine.

I present my argument by focusing my analysis on one particular narrative written by a man born in Karelia in 1930. The analysis concentrates on the description of a visit to Karelia decades after the evacuations. It reflects my research on the poetics of reminiscence writings based on a thematic collection of 182 such writings. My study analyzes two basic dimensions of narrative: the temporality of reminiscence writings and the position of the author in relation to the time periods of the narrated past and the present time of writing (e.g., Ochs and Capps 1996:23-8; see also Genette 1980:189-98). According to Michael Bamberg, a speaker or author makes a rhetorical choice when positioning him- or herself in relation to the described events of the story (2004:358-9; see also Bamberg 2005; Kirshenblatt-Gimblett 1989; Portelli 1997:85-6, 132-8; Bauman 1986:112-3; Bakhtin 1981:255). The analysis of a large corpus of writings about evacuation journeys enabled me to identify typical and recurrent models of both authorial positions and temporal organization. It also allowed me to discern different thematic content typically associated with these positions, in order to better perceive the generic and intertextual relationships reflected by these structures and content and what types of meanings these connections convey. Hence, a writer's choice of position can be interpreted as a reference to a certain kind of generic framework as well as to a large potential of meanings attached to this framework. I chose the specific example for this article on the grounds that it contains several poetic qualities that are relevant to and representative of the writings of the collection in general. 


\section{Intertextuality, Genre, and Narrator's Position}

The view of genres as communicative frameworks for the production and interpretation of discourse informs my research (Briggs and Bauman 1992; Hanks 1987; Bakhtin 1981, 1986; Bakhtin and Medvedev 1978; also Fowler 1982). According to Mikhail Bakhtin, language materializes as concrete oral and written utterances created and used by people in the various spheres of human activity. Each utterance reflects these respective spheres through its content, linguistic style, and compositional structure. Hence, certain kinds of communication situations tend to lead to specific and relatively conventional types of utterances known as speech genres, which are quintessentially attached to sociohistorical contexts (Bakhtin 1986:60, 87; Seitel 2003:278; Allen 2000:28, 36; Dorst 1983:414-6, 425).

Following Richard Bauman, I understand intertextuality as a text's orientation toward other texts, and I analyze it as discursive practice (Bauman 2004:4; see Bakhtin 1986:162). Genres are also fundamentally intertextual. Generic intertextuality means that the utterances that follow and can be recognized as representing a certain genre not only refer to earlier expressions produced in the framework of the same genre, but also acquire generic conventions from them (Briggs and Bauman 1992:147; Bauman 2004:5-6). Different genres have the tendency to organize time and present the relationship and distance between a narrated event (the past) and narrative event (in this case, the moment of writing) differently (see Bauman 1986). For example, in oral history testimony the narrator typically has an important and visible role both as a person who experienced the past and as a person describing history. First-person narrator and eyewitness observations give the account its authority as a testimony (Tonkin 1992:40-1; Portelli 1997:84; Peltonen 1996:114-6; Heimo 2010:63-4; see also Shuman 2005:151). In (modern) historical representations, the narrator is often distant or absent from the described event, and the resulting discourse creates the impression of objectivity (see White 1987:2-4). These culture-, time-, and genre-specific poetic devices supply the narrative with specific kinds of meanings and authority. Authors of evacuation journey narratives use and refer to other texts as well as poetic and genre conventions in order to create their own texts and utterances with certain kinds of meanings. Writers recognize traces of meanings from earlier and genre-specific sociohistorical contexts that intertextual relations embody, and they automatically use this knowledge in order to express themselves in ways felt to be appropriate and effective (see Bakhtin 1986:78-9, 80, 92).

Bakhtin emphasizes the extreme degree of variety among speech genres, and he differentiates between simple and complex speech genres. For example, complex speech genres include novels, dramas, and works of scientific research, which are formed in "comparatively highly developed and organized cultural communication (primarily written) that is artistic, scientific, sociopolitical, and so on" (Bakhtin 1986:62). In the course of their development, complex genres incorporate various simple genres such as rejoinders in dialogue or proverbs (60-2). Many researchers have noted that personal narratives sent to collection campaigns typically mix different literary conventions and narrative genres (Pöysä 2006:231; Latvala 2005:48; Kaarlenkaski 2012:146-99; Peltonen 1996; see Sheridan 1993:32-3; Ochs and Capps 1996:19-20). 
This heterogeneous group of texts is comparable to the Bakhtinian complex genre, being formed in (written) cultural communication. The writings include and use simple genres such as quotations from old diaries, poems, or lyrics of religious hymns. In addition, the writings contain intertextual links to other complex genres such as documentary prose (including historiography) as well as more fictional genres such as idylls, pastoral literature, and myth narratives (see Bakhtin 1986; Portelli 1997:4-5; Savolainen 2016). Despite the existence of a vast amount of research on reminiscence writings in Finland, there has not been sufficient discussion about their meaning in terms of generic layering and intertextual implications. This article thus supplements the existing research on personal experience narratives by analyzing values and meanings connected to and mediated through generic intertextuality in the context of reminiscence writings.

\section{Collecting and Researching Written Reminiscences of the Past}

The thematic collection called Children's Evacuation Journey (Lasten evakkomatkat) was organized in 2004 by the Finnish Karelian League in collaboration with the Finnish Literature Society's Folklore Archive. ${ }^{2}$ The Finnish Literature Society played an essential role in the development and establishment of organized folklore collecting in Finland in the nineteenth century. With the establishment of the Folklore Archive in the 1930s, a network of collectors started to take shape as a body of respondents producing folklife materials and eventually also written narratives of personal experiences (Pöysä and Timonen 2004:222-33; Latvala 2005:24-5; see also Thompson 1961; Richmond 1961; Abrahams 1993:16, 20).

Writing collection campaigns and competitions on a given theme are frequently organized in Finland today by various archives and museums, often in cooperation with a civic organization, company, or researcher with an interest in the topic. The themes of such campaigns, often related to significant historical events, may also include quotidian life. These writings are somewhat comparable to the materials generated by the Mass Observation in Great Britain, for example (see Sheridan 1993); they may resemble autobiographies, memoirs, or oral history testimonies, and their lengths and structures vary. They also frequently refer to performances or situations of oral communication (see Latvala 2005:65). A specific feature of Finnish (and more generally Nordic-Baltic) scholarship of personal narrative is the application of ideas and premises from oral history research to the study of written reminiscence narratives (Heimo 2016; Kuusisto-Arponen and Savolainen 2016; Peltonen 1996; Latvala 2005), with emphasis on narrative form and structure in addition to thematic content.

The creation of a collection of writings and their particular contextual meanings as responses sent to this collection can be compared to the role of the interviewer in the creation of an oral history narrative (see Abrams 2010:26-7). An organization or an archive initiates the dialogue by inviting people to submit writings about a certain theme. Writers then respond to this appeal (Latvala 2005:56-8, 65; Pöysä 1997:39). The organization formulates the theme, goals, and interests of the collection in an announcement that can be sent directly to potential respondents and published in different media. Announcements can include a detailed list of questions, or they can 
be more open in their form. In the case of evacuation journey writings, the Finnish Karelian League published the announcement in their own newspaper and as a press release. The announcement, open but multifaceted, posed the question: "How did children experience the evacuation journey?" The aim of the Karelian League was to "collect memories of childhood evacuation journeys." Writers were asked to write about their "experiences, memories, and stories" related to the evacuations. The authors were also informed about the possibility of publication or research of the collected materials. ${ }^{3}$

The personal motivation for participating in thematic collections and competitions varies from collection to collection and from writer to writer (Latvala 2005:36; see also Sheridan 1993:32). The motivations of the respondents included in my research material can be summarized in terms of three overlapping categories that also reflect the aims of the organizer as outlined in the collection announcement. The most common motivation of writers of evacuation journey narratives is to provide testimony and a record of their memories for future generations. Karelian evacuees seek to underline that they were part of an important historical event. Also, identity work motivates many evacuees to participate in this particular collection campaign. These writers demonstrate interest in reflecting on the roles of memorable, significant, and sometimes traumatic childhood experiences in the formation of their selves and lives. Many emphasize the therapeutic value of reminiscing. A third motivation is an artistic one; some writers want to create texts that are aesthetically marked pieces of literature rich with nuance. Often these motivations overlap and are simultaneous. For some writers, one of the motivations is dominant, whereas for others, the motivations are equal in value (Savolainen 2015:105-36).

Writers do not necessarily follow the collectors' request for a specific set of answers or point of view; sometimes their accounts diverge from such requests. The relationship between the organization initiating the collection on a particular theme and the respondents has been given critical attention in Finland for some time (Latvala 2014:120; Pöysä 1997:39-42; Mikkola 2009; see also Dolby [1989] 2008:59-63). In addition to the questions posed, the role of the organizer (for example, the organization's current or past political stance) may influence who responds and how (e.g., Peltonen 1996:132-3). The topic of "Lost Karelia" and the question of whether Russia should reassign the territories in Karelia to Finland is not a neutral or purely historical one. The question of restoring the ceded areas back to Finland still comes up in public discussions, and there exists at least one organization that publicly supports their return (Fingerroos 2008:239, 246-9). A clear majority of the writers represented in the material I analyzed, however, do not subscribe to a wish for these lands to be returned. Their interest in Karelia is more connected to their roots and identities (see also Alasuutari and Alasuutari 2007:96). This also reflects the current neutral position of the Finnish Karelian League on the so-called "Karelian issue." The League does not actively promote the annexation of the area from Russia to Finland, but rather focuses on the preservation of Karelian cultural heritage (Finnish Karelian League 2005). On the other hand, the organizer of the collection may have either softened the articulated viewpoints of persons in favor of the reassignment or prevented them from participating altogether. 


\section{Karelia and the Evacuations}

Between 1939 and 1944, Finland fought two wars against the Soviet Union: the Winter War (1939-1940) and the Continuation War (1941-1944). Both of these conflicts resulted in the cession of parts of the Finnish Karelian province, the Karelian Isthmus, and the western and northern coasts of Lake Ladoga-among other parts of Finland - to the Soviet Union. During and after both of these wars, the Finnish population living in ceded Karelia was evacuated behind the new Finnish border. A new group, the "Karelian migrants"-or the "Karelian evacuees"-was born.

In the Continuation War, Finland was allied with Germany. In 1941, at the beginning of this war, Finland reconquered the lost territories of Karelia (and more) from the Soviet Union, and about 70 percent of the evacuees moved back to Karelia while the war was still going on. In 1944, however, Finland pulled back from the war for good, again ceding Karelia to the Soviet Union and evacuating those who had returned to Karelia back to Finland. The number of Karelian evacuees totaled 407,000 people, nearly 11 percent of the national population at the time. The Karelian evacuees were resettled in new dwelling places, while Finland paid reparations to the Allied governments (Lavery 2006:130; Armstrong 2004:1-2; Fingerroos 2008:237; KuusistoArponen 2009:545-6).

While the events of the Second World War undoubtedly reinforced the symbolic value of Karelia, the difficult geopolitical situation between Finland and the Soviet Union made discussions related to Karelia and cessions of territory sensitive during the Cold War. For this reason some Karelian evacuees felt unable for a long time to publicly discuss and grieve the loss of their homes. Kirsi Niukko describes the remembrance of Karelia in postwar Finland as a counterculture (2009:66). Such tensions also reflect the significance and symbolic value attached to Karelia rooted in history. Often described as a battlefield and as a border between the East and West (Paasi 1996:87), Karelia already represented a symbolic center for Finnish nationalism. This idea dates back to the cultural and scientific movement of Karelianism, which flourished among the Finnish intelligentsia in the nineteenth and early twentieth centuries. Karelia was a place that inspired artists, authors, and scholars. For example, Elias Lönnrot made several trips to Karelia to collect folk poems for inclusion in the Finnish national epic Kalevala, which supported the rise of folkloristics as a scholarly discipline and deepened interest in Karelia (Paasi 1996:92; Armstrong 2004:2; Fingerroos 2006:97-8; 2008:238; Alasuutari and Alasuutari 2007:93-4; Sihvo [1973] 2003). Later this locus of ideas, emotions, and symbols connected to Karelia would be widely recognized and studied.

It should also be emphasized that Karelia is a multicultural, multilingual, and heterogeneous region (Paasi 1996, Fingerroos 2008:235). Even Finnish Karelian evacuees cannot be considered a homogeneous group. The majority of evacuees (and the writers included in my research material) are Lutheran Christians, as are most Finns, but some are Eastern Orthodox. Evacuees also hold different political views. Thus, not all evacuees feel that they have a lot in common, and their identities in terms of Karelian roots may differ (Alasuutari and Alasuutari 2007:96-7).

According to postwar research, the evacuation and resettling of Karelian migrants exemplified a successful emigration and adaptation process (Waris et al. 1952). Since 
the 1990s, however, discussion on the issue has splintered, and past research has been criticized for being too positive about the displacement experience (Paasi 1996; Kuusisto-Arponen 2009:546-7). My research material includes both positive and negative descriptions of what being an evacuee meant as well as positive and negative views on the outcomes of the evacuations. The writers often highlight how well they were treated by other Finns who gave them a temporary home. They also tend to report that they are happy and satisfied with life, even though they lost their homes. Some writers emphasize the positive energy and strength that stem from Karelian identity and shared experiences of survival. In addition to these positive views, the material also reflects the experience of shame or silence on the topic of Karelian roots and lost homes as well as feelings that their personal experiences as evacuees have not been properly understood. Many writers express the perception that they were a burden on those who gave them accommodation (Savolainen 2015:304-8, 329-38).

Due to the theme of the collection campaign, the point of view of children is especially common in my research material. Often writers share their memories of feeling at the time of the evacuations that the adults could not understand the children's fears or joys and thought that the children experienced less true hardship than the adults. Some writers also express that they had to assume too many responsibilities at a young age because of the war and the loss of their home (Savolainen 2015:316-28). The reality of the evacuation journey was a reality of war. Thus, recurrent topics in the accounts of evacuation journeys are fears of war, losing a parent, or being left alone. Karelian child evacuees typically made the evacuation journey from Karelia to Finland with their families rather than alone, often by train while the war still raged. The front was near Karelia, and railroads were tactically important targets for bombing. Therefore, many writers describe bombings and the ensuing chaos (Savolainen 2015:119-24). Many writers also describe births or deaths during the evacuation journey, including the deaths of elderly people vulnerable to the hardships of the journey-such as travelling in dark and crowded stock cars that lacked basic amenities. Accounts of both births and deaths emphasize the journeys' dire conditions and the evacuees' lack of control over their own lives. In the narratives, these passages function to metaphorically parallel the evacuation journey with the border between life and death (Savolainen 2015:256-64). Fear and shock are often described in reminiscence writings from a child's viewpoint through sounds, smells, or inexplicable visions, or they are depicted as traumas (Savolainen 2015:119-24, 272-5). Even though evacuation journeys were in many ways shocking events, my research material also includes accounts of peaceful and safe journeys, as well as descriptions of the journey as an adventure (Savolainen 2015:256-67).

Currently Karelia is a diversified area located in the Russian Republic of Karelia, the Russian Leningrad Oblast, and Finnish South and North Karelia (see also Fingerroos 2008:235). The eastern border of Finland has remained the same since the Paris Peace Treaties in 1947. Evacuated Karelians were not able to visit their former homes in Karelia for decades after the war, as most areas of Russian-controlled Karelia were completely prohibited for tourists. Soviet resettlement began immediately after the Winter War in 1940, but the population of new Soviet inhabitants was evacuated when the Finnish army invaded Karelia in 1941. After the Continuation War, the 
Soviet Union again resettled the formerly Finnish areas in Karelia (Laine 2005:31-6; Paasi 1996:283-4; Hakamies 2005). Some of the new inhabitants moved to Karelia voluntarily, but others were more or less forced to move there. Some villages were also left empty. The new inhabitants migrated from different parts of Russia, Ukraine, and Belarus, and the Finnish place names were replaced with Russian names.

The Soviet Union began to allow Finnish tourists to visit the biggest city in Karelia, Viipuri, in the 1960s. The rural countryside of the ceded areas remained closed to outsiders until the latter half of the 1980s. Perestroika and eventually the collapse of the Soviet Union made tourism and visits to former homes in Karelia possible on a larger scale. Since then thousands of Finnish Karelian evacuees have visited their former home regions every summer. Typically families or associations of Karelian evacuees organize these excursions. The majority of participants are evacuees or their descendants, and the visits appear to create new shared experiences among the evacuees. Usually made by bus, the journey accentuates concrete feelings of togetherness and a sense of community among members of the group. When they cross the border and enter the land of their lost homes, they do it not so much as individuals but together as a group (Lehto and Timonen 1993; Paasi 1996:282-9; Fingerroos 2007; Niukko 2009; Alasuutari and Alasuutari 2007:94-5; see Basu 2006).

\section{Between the Karelian Dialect and Standard Language}

In the remainder of this article, I analyze an account of a trip to Karelia written by a man, Jakkko, born in 1930 in Johannes. ${ }^{4}$ The narrative is 21 pages long, of which five pages describe his trip to Karelia in May of 1990. The journey to his home region is one of the most important themes in Jaakko's narrative; he has repeatedly visited the area since 1990. One noteworthy aspect of this particular narrative is the author's alternation between two different modes of language: standard Finnish and the Karelian dialect. The alternation of these two modes occurs throughout the writing, and Jaakko makes a clear distinction between them. The parts in dialect are heavily marked, as Jaakko has italicized and indented them. ${ }^{5}$ The description of the trip to Karelia begins with a brief report of the situation in Jaakko's hometown in Karelia during the time between the evacuations in 1944 and his return visit in 1990. He then describes the actual journey, beginning with a chronological description of a trip from place to place within the town, without any explicit personal viewpoints or reflections. As marked by the use of italics below, a shift occurs in the narrative when Jaakko begins describing his arrival at his old home in Karelia:

When a rainy and grey night started to grow dimmer and we yet had to make it to Hotel Lokki at the township to check in and have dinner, we had one more hour "to be at home." Instantly little groups were formed that headed for their own home yards.

There were three of us neighbours and childhood playfellows on the journey-Maire, Pauli, and I-and we quickly went in our own direction. We went through the neighbour Eetvartti's yard and next to the forge to the village road of Hankala. All the while someone said: "Can you remember when ...?" and then we chatted about what happened at that spot or where that path led or anything else that the memory brought to 
mind. And the discussion went on. When one stopped, another continued reminiscing, and the old happenings welled up in the mind.

The closer we got, the faster we went. We went past the Iitamari's swamp and "crossed pine tree" and then we were at our old playfield next to my and Maire's homes. Pauli's home was a little bit further. Everybody ran the rest of the journey to their home yards, and as the yards were close to each other we shouted our observations to the others.

The buildings of the village of Hankala were all pulled down, all the way to their foundations. There were only foundation stones and a piggery made out of stones left and the parts of the cellar that were made out of stones. There were already large trees growing inside the foundations. The yards were still open. Only a few saplings of spruces were growing in our yard. Birch trees and alders had started to grow in the ditches of the shore field, but you could see the bay of the sea almost as well as before.

Because time was limited and we wanted to see as much as possible, we decided to leave the thorough investigations of the home yards for tomorrow and we went with Maire to Pauli's home... . Time started to be up and we had to hurry to Salminiemi. The hour went quickly, but during the hour we had seen a lot, and even more were the feelings in the bottom of our hearts. To come to the home yard after many decades is one of these moments that made your eyes wet and mind emotional!

Unconfirmed information says that German prisoners of war had pulled down the buildings of Revonsaari immediately after the war. No information has been found about where the buildings were taken. ${ }^{6}$

When Jaakko uses standard language, he distances himself from the described events. He situates himself clearly in the time of the writing and reminiscing. He uses standard language in order to document and narrate the "true" events and facts, not so much to describe or reveal his subjective experiences and vivid and crystallized memories. The sections in standard language frame the parts in dialect, which the writer has italicized and indented. These framings offer basic information about the course of the journey such as places, environments, conditions, and the change of place. This information orients the reader for the more personal parts in Karelian dialect.

The shift between the two different modes of language also marks a change in the narrator's position. Jaakko uses Karelian dialect when reflecting on and describing his personal experiences, impressions, and emotions on the way home and when finally reaching his home. The dialect style includes fragments of quoted speech that refer to childhood times. One function of these quotations is to indicate that he belonged to a group that shared the experience of going back home. In addition, the fragments of quotations indicate a process of reminiscing. They function to reveal the evocation of the past in the imagination of the visitors as they encountered their childhood places again. At the narrative level, the description about the experience of the childhood home after so many decades creates an account of time travel. Travelers find that the landscape has changed in relation to their memories of the same place. Despite changes in the environment, however, they find confluences between then and now, and the memories begin to arise in their minds (see Lehto and Timonen 1993:97). 
The use of written dialect in this example is not an exception in my research material. The collection announcement did not, however, ask the writers to use dialect. Each made the decision independently. The Karelian dialect is used in the larger collection of reminiscence writings of child evacuees in two ways: first, it is found in momentary switches from standard language to dialect (as reported speech, for example); second, it appears repeatedly as a dominant mode of narration. The first way of using dialect is very common in my research material, but the second is rarer. Both are found in the example text. The use of Karelian dialect typically expresses identity negotiations and performances in the social reality of evacuations. Often it is connected with encounters and boundaries between persons coming from different places. The use of dialect may also express the writer's pride in his or her Karelian roots and heritage or depict a person using the different dialect as humorous (Savolainen 2015:178-91). Literary scholars have made similar conclusions on the function of written dialect in the case of Finnish literature (Kalliokoski 1998:189-90, 194; Penttilä 1945; Laitinen 1997).

In this example, the alternation between the formal mode and the dialect mode reveals differing levels of association: the former distances Jaakko from described events whereas the latter underlines his involvement in the events he is recounting. This is comparable to observations of code-switching in oral communication. Researchers have shown that code-switching may indicate, for example, a change in the speaker's viewpoint and position (Goffman 1981), as well as evocation of a new context (Myers-Scotton 1993). In addition, it may have an ideological dimension (Hill and Hill 1986). Furthermore, code-switching between dialect and standard language has a social function (Blom and Gumperz 1972; Penfield and Ornstein-Galicia 1985:14-5; Gumperz and Hernández-Chávez 1972). In the case of the evacuation journey writings I have examined, code-switching between Karelian dialect and standard language serves all of these functions; dialect is associated with the social reality of diaspora and migration as well as the values and social negotiations connected to them.

Jaakko continues his narrative by describing the return to his home yard the next day:

Yesterday's rainy clouds had vanished and now the sun was shining. Only light clouds were wandering through the blue sky. It felt like nature had prepared itself to warmly greet us after decades of absence. ... I sat in the sun on the foundation stone of my home, closed my eyes and lifted up the buildings in my thoughts. The decades vanished and I was again in the similar yard as it used to be before!

Next we gathered together again. When we were there, near to our old playground, I said, let's go and see our old place for the high jump. First we went to a couple of pine trees, but it was not the right set and we didn't find anything. Then we went to the next pine trees and it was the right set. I just barely stroked the pine bark and I found one rusty nail. At that spot was our old high jump! Now the rusty and crooked nail is at the best place in my cabinet of trophies! . . A person's memory sure is amazing. When I wandered in the landscape of my childhood, loads of images of the old times kept coming to my mind! 
This excerpt includes an account of travel in time, in which the narrator shifts from the world of journeying home to the world of childhood and memories of experiences from the past that had been forgotten. He emphasizes this shift by switching from standard language to dialect. Using standard language, he tells how he sat in the ruins of his former home, closed his eyes, and imagined the buildings that used to stand in that place. The description is about how the experience of being in a concrete place activated the writer's memories of that place from years ago and how the place enabled him to feel something that approached the experience of childhood. The excerpt includes the reality of the journey to his former home and a reality in which experiences of the place in different moments of the writer's life were conjoined. The atmosphere of the latter stratified reality is described as special, something far from mundane.

This example also reveals an interesting detail that relates to the use of dialect, particularly in the reminiscence writings of child evacuees. When dialect is used as a mode of narration, it creates a special fictional reality in the narrative that often reflects a child's point of view. In the case of this example, the use of dialect represents a shift from the reality of adulthood to the reality of childhood and from an adult's understanding to a child's consciousness and state of mind. The use of dialect promotes the evocation of childhood and the past in the narrative. The shift to dialect also momentarily narrows the distance between the moment of writing and the moment of the event, as if the writer has immersed himself in the described events. Therefore, the switch from standard language to Karelian dialect can be seen as an example of performative language that, for instance, is reminiscent of the use of the conversational historical present (Laitinen 1998; see also Wolfson 1979).

These two modes of language are also connected to the two intertextual frameworks typically prevailing in the reminiscence writings of child evacuees. The use of standard language is connected to conventions that are typical of the genres of documentary representation. As for the use of Karelian dialect, it is connected to a variety of generic conventions that are typically associated with genres of fiction such as nostalgia discourse and idyllic representation. In narrative reminiscing, these two frameworks, as well as the modes of language that represent them, work in cooperation. They support and contrast each other, creating meanings together in relationship with each other. The passages, which are connected to nostalgia discourse, make documentary details more vivid and alive. Facts verify more personal and fictional parts, locating them in a shared sociohistorical context. In other words, the interplay between these generic frameworks allows the writer first to take artistic liberties from the more formal and fact-based description of what happened-making shared history more intense, animated, and contextualized from the viewpoint of the writer's personal experiences-and second, to give individuals' memories and experiences authority as testimonies of history, locating them in a shared sociohistorical context.

\section{Telling the Truth: The Use of Evidence and Sources in Reminiscing}

Memories, impressions about the past, and self-understanding are very much intertwined with concrete and physical objects and places (e.g., Kuusisto-Arponen and Savolainen 2016; Glassie 1982; Basso 1984; Lowenthal 1985; Connerton 1989; Tonkin 
1992; Siikala and Siikala 2005). This example represents the tangibility of reminiscing. When Jaakko describes the moment he returns to his home yard after many decades, he includes the detail of the rusty nail-a concrete object that represents a trace of the specific place and the past. It has transformed into a travelling object or a memento, metonymically symbolizing the venue of the high jump even when placed somewhere else (Lury 1997). In my research material, travelling objects cause temporal stratification of the narrative and promote sudden leaps between periods of time. In the case of the example, the rusty nail activates a third time-reality. The memento is included in the time period of the moment of writing, as it is explicitly present in the narrative. The first reality is the most ambiguous and distant, the fictional or mythical time of childhood, when the high jump was in use. The second reality is the time of Jaakko's first journey to his former home at the beginning of the 1990s, when he found the rusty nail in a pine tree by the old high jump spot. The third reality is the time of the writing, when the rusty nail was in the cabinet of trophies at Jaakko's present home. This description shows how the experience of the concrete place that is present both in the past and in the present, as well as the material memento, can enable narrators or persons remembering the past to form a link and continuum between different moments in their life and between spatial locations. These can be seen as material pieces of evidence of the past, "testimonial objects" that condense meanings and experiences related to places and different periods of life (see Hirsch and Spitzer 2007; see also Kuusisto-Arponen and Savolainen 2016).

The example of the rusty nail shows that temporal connections between the past and the present are created in children's evacuation journey writings through the use of rather concrete tools. In their narratives, writers include concrete evidence or sources of the past that can be seen as confluences of the past and the present. Such types of evidence testify to and represent past events and places, creating a tangible link to days gone by. Evidence is also used in the present, but its power and character as evidence is based on its ability to create a bridge from the past to the present. The evidence used in children's evacuation writings can be roughly divided into documents, mementos, and bodily traces. Documents can be personal-like old journals, photographs, or letters-or they can reference or even quote history books or research on war history. The use of documents in writings often includes detailed information with dates and place names, which can reflect an intention to produce new sources (for example, for the sake of historians or an archive) (Kuusisto-Arponen and Savolainen 2016; Savolainen 2015:218-26; see also Toker 1997:187, 190-2). In the example here, Jaakko describes the photographs that have become documents of the past:

\footnotetext{
Already the same day we returned to Viipuri and through Nuijamaa back to Finland. A long time after the trip, I wandered in Revonsaari in my thoughts and looked at the landscapes of the island with the eyes of my soul. When the photographs that I took during the journey were ready, I travelled many times the same routes that I wandered on the home island. ${ }^{8}$
}

This excerpt clearly shows how the photographs from the journey to the home region have turned into documents. They not only serve as evidence and a reminder of the time period of the journey, but they also enable the writer to imagine and experience 
the home place in spite of restrictions of time and place (see Hirsch and Spitzer 2007). He uses the photographs in the creation of a spatiotemporal link, which essentially allows him to travel in time. However, the photographs alone are not enough for time travel to happen. Jaakko implies that seeing and experiencing the concrete physical place enabled him to travel there in his mind when later looking at the photographs taken during the journey to his former home. The experience of seeing the childhood place again unlocked the temporal and locational restrictions of reality, and the photographs maintain this state.

The second type of evidence I have named "mementos." They are concrete objects, like the rusty nail, that writers refer to in their writings. In the case of Karelian evacuees, mementos often relate to Karelia, the home place, and the evacuation journey; they are parts of them. Examples may include soil, objects, or cuttings or seedlings of plants. Sometimes mementos become sacred and are used in rituals such as christenings (e.g., water from Karelia) and funerals (e.g., soil from Karelia). As metonymical objects, mementos represent and symbolize meanings relating to the whole, such as the span of generations connected to the home that has been lost or the evacuation journey as an event that strongly defines the community of Karelian evacuees (Kuuisto-Arponen and Savolainen 2016; Savolainen 2015:226-8; see Lehto and Timonen 1993:99-100; Peltonen 2003:174-86). In the case of the text examined here, the writer has created a metonymical way to travel, as the rusty nail transports him to the childhood place of the high jump, and the photographs of the place transport him back to the landscape of Karelia. In addition to the spatial aspect of this travelling, it has a temporal dimension: these mental journeys also create a fictional reality in the narrative where childhood experiences blend together with later experiences.

The third kind of evidence that appears in reminiscence writings consists of bodily traces. These are concrete marks on the writer's body such as scars or other physical traces (for example, from the long-term bodily effects of nutritional deficiencies). Bodily traces can be mental or emotional, such as traumas or experiences of insecurity or fear, or they can be based on the senses, such as memories of smells, sounds, and tastes (Savolainen 2015:300-3, 270-5, 119-25; see Pink 2009:37-8; Kuusisto-Arponen and Savolainen 2016; Hamilton 2011).

These three kinds of evidence or sources conjoin in different ways when individual writers apply them in their evacuation journey writings. The boundaries between different kinds of evidence are vague and overlapping, as a document can also be a memento, and a memento can attach itself as a bodily trace. What makes these three kinds of evidence (but especially mementos and bodily traces) similar is that their function as links between times is based on the fact that they exist both in the past and in the present, thus enabling an experience of historical immediacy (Lowenthal 1985:247). I suggest that the use of these types of evidence can also be seen as a discursive parallel practice to the use of standard language described in the previous section. In the case of the example narrative, the use of evidence-as well as the parts of the text where the standard language is used-creates links to different genres of documentary representation such as testimonies and history-telling. These intertextual relations are utilized in order to give the reminiscence narrative certain kinds of meanings. Connections to genres of documentary representation immediately 
produce a certain frame of interpretation of the narrative as well as of the writer's intentions and goals toward telling and reminiscing about his or her past. In terms of framework, it is apparent that Jaakko is seeking to highlight the referential quality of his reminiscing.

The intertextual function of the typical types of evidence used in reminiscence writings is based on two kinds of mechanisms. First, when writers refer to "official" documents or historiography, they appeal to the professional or institutional authority of such evidence in an attempt to increase the credibility of the narrative. A writer who includes evidence in the reminiscing highlights her or his commitment to the truth (in other words, she or he is not making up the events). Exact times, places, and name information as well as mementos and bodily traces have a function of convincing and providing evidence about congruencies and links between the past and the present. This is to say, past events do exist on some level in the present as well. In some cases, exact information can also highlight the political relevance of events and places (Huttunen 2007:182). In the case of evacuation journey narratives, highlighting the lack of factual information or citing the poorness of one's own memories of the past can also be interpreted as rhetorical tools of the writer to convince readers of her or his intention to speak truthfully. Intertextual connections to genres of documentary representation also highlight the collective nature of past events that are connected to personal memories and narrative. Places on the journey and home places are often called by their names in migrant Karelians' narratives, and events that relate to these places are concurrently given meanings in terms of precise moments in time (Willman 2006:154; Savolainen 2015:228-34). Exact historical dates and the naming of places and events promote comparisons of experiences and locate them in relation to shared history and geographical location. In other words, places become identifiable in space and time. Second, when writers refer to personal sources (such as journals or photographs, mementos or bodily traces), they lean on their own position as eyewitness with firsthand experience of the past. In the case of the text here, through the use of different types of evidence, the writer intertextually underlines that his narrative is based on true events despite somewhat fictional elements such as the accounts of mental travel across time and place. In addition, these types of evidence function as tools of memory and narration. They provide writers with a point of reference or a basic structure to which they can attach personal memories and build a narrative about the past (see also Kuusisto-Arponen and Savolainen 2016).

In the case of reminiscence writings, different types of evidence and sources seem to collect or elicit memories and narratives from different temporal levels. In the words of Edward Casey, they have "gathering power" similar to significant places (1996:24, 44; see Pink 2009:30-1). Their quality as such appears also at the level of narrative. Typically the plot formulations of evacuation journey narratives follow two different kinds of logic. Often the narrative follows a chronological order; for example, the evacuation journey is described as a chronologically sequential chain of named places. However, in the process of narration, some links in this chronological chain are connected with evidence and sources that are associated with events, persons, and memories from several time levels at that particular point in the narrative. These spots appear as breaks in the chronological linearity of the plot. In these ruptures, 
several periods of time-such as different pasts, the present, and the future-come together. They operate as nodes that connect networks of associations and memories and then activate them. At the level of the narrative, evidence produces a locus where the intersection of two temporal modes of narration unfolds. These spots represent three-dimensional expansions in which the two basic logics of plot formation introduced by Roman Jakobson, one building on combination and the other building on selection, are encountered (1987:97-100, 109-14; see Hastrup 1987:262-3; Portelli 1997:101). In the case of reminiscence writings, these logics neither appear as alternative nor they exclude each other. Moreover, in narrative and memory they mix with, support, and complete each other. Time levels and associations linked together by a place, source, or memento show that in reminiscing and narrating, writers create the coherence of their life stories and experiences.

\section{Nostalgia and Idyllic Pasts: Production of Continuation by Creating Difference}

Intertextual relationships with documentary representation basically connect different times together through the process of reminiscing. The role of evidence is vital in this kind of narrative argumentation and rhetoric. Different types of evidence concretely reflect a continuum, as it is their essential nature to exist in the past as well as in later times as similar and enduring objects. Connections can also be created by emphasizing differences between eras with special characteristics. In the case of the reminiscence writings of Karelian child evacuees, another intertextual framework that is especially relevant (in addition to the genres of documentary representation) is built around genres related to nostalgia and idyllic representation. Idyllic descriptions of a place or an era-and nostalgia in general-are an example of this kind of connection. Used in the creation of a continuum between eras by emphasizing differences as well as specific qualities and values, their logic is that the value of each era or place is determined in relation to the quality of another era or place. For example, the past becomes glorified not by itself, but in comparison to a not-so-wonderful present.

In the case of Karelian child evacuees, it is quite apt that the original meaning of the word "nostalgia" refers to a medical disease that results from homesickness (Chase and Shaw 1989). Originally seen as a sentiment related to a place, nostalgia has become increasingly understood as temporal longing (Wilson 2005:1-3). According to Svetlana Boym, nostalgia is defined by longing for a different time and the anguish caused by temporal distance and displacement (2001:xv). It is apparent that Karelian evacuees direct their nostalgic gaze not only toward the places of their former homes, but also toward their childhoods of the past. Therefore, time and place are interchangeable in this nostalgia. The time of a place that is longed for can be primarily individual, collective, or historical. It can also be a time that never existed, as Andrew Wernick points out (1997:219). Nostalgia can then produce utopian realities. From the viewpoint of generic intertextuality, nostalgia shares a similar logic with such genres as idylls and pastoral literature. What seems to be shared by these different genres is that they draw from the past and are directed toward the future as hopes, wishes, and fantasies. Nevertheless, the reader or listener tends to interpret these texts from the 
viewpoint of the relative present. Hence, the tripartite temporal logic of nostalgia is similar to historical inversion, a temporal trans-positioning that, according to Mikhail Bakhtin, is typical of folkloric chronotopes, reflecting mythological and artistic modes of thought. In historical inversion, things that can only be realized in the future (such as hopes and wishes) are portrayed as something in the past (1981:147).

The nostalgic imaginary of descriptions of lost homes in Karelia seen in reminiscences is similar to that employed by genres of idylls and pastoral literature. One characteristic of idyllic representation and nostalgia in the reminiscence writings of Karelian evacuees is that writers describe the Karelia of their childhood as a harmonious place where innocence, peace, and the happiness of everyday life prevail. Time seems to stand still in this idyllic Karelia. People live in harmony with nature and animals, and life in general is natural but naïve in a sublime way. These characteristics are similar to the features that Mikhail Bakhtin defined as typical for the genre of idylls or the idyllic chronotope (1981:224-5), which have many convergences with the mode of pastoral literature (e.g., Schiller 1800; Alpers 1996; Gifford 1999). Furthermore, Jaakko depicts the location of home in a way that is typical of idylls. Summer, light, warmth, and a harmonious atmosphere predominate the account. Nature in Karelia is also personified, as if it would support, approve of, and sympathize with his journey to his former home. This is a typical feature of descriptions of journeys to former homes (Lehto and Timonen 1993:93). Not all of the writings in the collection are as explicitly nostalgic or idyllic, but prewar Karelia and life there are described almost without exception in a positive tone in the material. Hardly any writers in my research material describe childhood in Karelia with bitterness or animosity (see Savolainen 2015:350-62). The idyllic chronotope of childhood Karelia excludes hardships and negative emotions. Troubles begin when the evacuation journey begins. Evacuation journey narratives describing an idyllic Karelia typically have a lyrical tone, and they are often highly coherent. Thus, the use of nostalgia in writing and reminiscing seems to be a choice of style that supports certain kinds of artistic expression. In addition, nostalgic reminiscences on some level enable narrators to empathize with and emotionally return to the experiences and feelings of their childhood.

The narrative of a lost Karelia also converges with the paradise myth. This idea complex includes the logic of nostalgia, as paradise represents the original (and lost) home of man and an object of eternal longing. In the reminiscence writings of Karelian evacuees, these generic intertextual ties are often implicit. However, sometimes they appear explicitly, as in the case of the following example narrative written by a woman born in 1936:

The Second World War had begun. I was left with lifelong longing for the home at the Karelian Isthmus and the happy days of early childhood. It is what they call longing for heaven. We miss the paradise from which we all were once driven away. It is the fundamental longing of the human, and the knowledge that we come from someplace better, from "the wonderful land," as they say in the old hymn. ${ }^{9}$

In order to be effective, the idea of a wonderful past requires the juxtaposition of a wretched present. The unavoidable consequence of this, however, is the destruction of 
the past. Stuart Tannock describes nostalgia as a structure of emotion that periodicizes time and always creates discontinuities (1995). The destruction of idyll serves the function of describing changes between different eras or worlds, such as the relationship between the enclosed world where people form a small, intact community and the greater world where people live without any contact with each other (Bakhtin 1981:228-36). In evacuation journey narratives, the division created by the destruction of the idyll reflects a common and basic pattern of constructing periods of time, which has also been seen as central for nostalgia. As Tannock writes, a new era follows a lapse of groundbreaking events that separates it from a preceding era (1995:456-7). The previous world - the past-thus becomes restricted to imaginary experience and the imaginary world of memories and narratives, which is distinguished from the present world. In this process, which represents the logic of nostalgia, the past is connected with place, and the whole is transformed from history into a collective or individual mythology, as Boym has noted (2001:xv). The world of the past acquires a mythic, symbolic status, and it becomes a crystallized image. In the case of the nostalgia of Karelian evacuees, descriptions of an idyllic Karelia and of losing it serve similar functions. The idealized gaze toward Karelia creates a division between the times before and after the evacuation journey, which also represents a division between the wonderful life in Karelia with a unified community and life outside Karelia in which all troubles exist and evacuees wander in separation. This division also represents a central threshold in the writers' stories of their lives, which appears in the narratives as a shift in the content, style, and tone of narration.

In the case of Jaakko's text, in spite of the contemporary experience of the lost Karelia and the changed landscape, the writer emphasizes that the place first and foremost represents the time of the past, memories, and childhood:

I think it is good that the buildings of our island have been pulled down and there is no habitation there. If home still were there with creaky buildings, as it is on the mainland, and there were strange people living in my home, I would have maybe visited there once. But now the situation is totally different. Now I can wander there freely through familiar roads and paths with no one disturbing me. I can let my memories come along with the views. When wandering along the village road, one can pop into the yards of houses, close one's eyes and raise the buildings as they used to be, reminiscing about the old residents. One may imagine how it would be there if the wars had never happened. ${ }^{10}$

Jaakko realizes that time has passed and that many things have happened in the home place in Karelia after the evacuations, but he does not want to include this dimension in his mental journeys. He is satisfied with the opportunity to reminisce about his childhood and childhood home, which has been made possible by experiencing the very same concrete place after decades. For example, he does not express any wish to actually move to Karelia or regain his ownership of the place. For him, both the place where he travels and the time that he imagines in reminiscing exist in a past without a future. This mental landscape has preserved his childhood world with a certain kind of atmosphere and details that are worth remembering. This does not, however, prevent Jaakko from referring to the mythical dimension of the alternative 
present in the last sentence of the excerpt. He mentions that if the war in the past would have had a different outcome, Karelia would not have been ceded, and the evacuees would have been able to return to their homes right after the war. From this viewpoint, imagined travels to childhood Karelia are also travels to this mythical reality of the imagination.

The atmosphere of the place and dimension of childhood Karelia depicted in Jaakko's narrative reminds one of an idyll. In descriptions of journeys to home regions, qualities of peace, harmony, solidarity, and consensus prevail among people of different nationalities, much as they do between people and animals in idylls:

\begin{abstract}
Based on myself or the other travelers home, I have discovered that hatred and bitterness toward the old villain are not present during the journeys. We have realized that the current residents of the Karelian Isthmus are not the ones to blame for us being evacuees. Home region journeys have been sort of a pilgrimage for me, a journey for strengthening memories of landscapes and a journey of recalling childhood memories. The most important part of the journey begins when Revonsaari first flashes through the window of the bus and ends when the island at last fades behind the forest.
\end{abstract}

Based on what I told before, it is rather probable that one more time, if the Creator allows me more days of living, I will again be at my home yard in Revonsaari as a boy who has returned from the evacuation trip. ${ }^{11}$

Jaakko does not express bitterness, anger, or animosity toward the present Russian inhabitants of Karelia. When he visits Karelia, he does not blame the Russians that he meets for the loss of Karelia after the war. The historical enemy has assumed a distant and nonhuman character, something that is different from the Karelian Russians, who are often described as friendly and helpful persons (see Niukko 2009:71). The experience of a sort of communion between people without a shared language that rises above strangeness and nationalities is a recurring theme in the descriptions of journeys to home regions. However, not all of the writers describe the return visit as a positive experience. For some, the site of childhood and memories has changed so much that it has become a completely strange place in Russia. In these cases, the current inhabitants are also described negatively as a faceless group, something akin to a historical enemy. The present decay of Karelia does not, however, diminish the value of the childhood paradise located in the same place, but rather highlights the loveliness of the past in a nostalgic way.

The writer Jaakko also emphasizes that these return visits to Karelia are, first and foremost, journeys to his memories and pilgrimages to his time of childhood. The Karelia he describes is a static world of pre-war childhood, and the nature of journeys to former homes is oriented toward the past. Therefore, they are not only travels to places and between places, but journeys in time. The writer describes this experience by depicting himself as a boy again when he reaches Karelia and the place of the childhood home. In a way, the special and sacred place enables him to travel back to his childhood time and consciousness. Orientation toward the past does not, however, mean that the past does not have any value from the viewpoint of the present or the 
future-rather, it is quite the opposite. The generic and crystallized idea of an idyllic Karelia, which is created by the nostalgic view, also has symbolic value. It represents not only a place of the former home, but also a chain of generations, a temporal chain that is interconnected with the place and forms a specific imaginal world that is "sufficient unto itself," as Bakhtin described idylls (1981:225).

The poetic formulation of this experience in the reminiscence narrative also requires the creative use of different discursive means, such as intertextuality. In the case of the reminiscence writings of Karelian evacuees, links to idylls and nostalgia discourse-as well as language and narrative choices, which are often considered as atypical for life writings and narratives of self, such as the use of present tense, written dialect, and flexible and mutable focalizations-enable writers to convey experiences that would be difficult to express with standard language. It is also not a coincidence that the term "pilgrimage" occurs in the narrative. As a common metaphor in descriptions of journeys to home regions, it implies that the experience of going back to the concrete place of childhood and the experience of time travel that the journey generates are like sacred occurrences, which cannot be explained with everyday logic (Lehto and Timonen 1993). Indeed, reminiscing not only means recalling past events and happenings, but also developing them and creating new experiences in the present. Clearly, one reason why people reminisce and actively seek to find links between the past and the present is also that it is amusing and enjoyable.

\section{Conclusion}

Intertextuality is a discursive practice prevailing in reminiscence writings. Intertextual connections reach beyond the relationships of texts and utterances to links between genres and conventional means of expression, which are always connected to the sociohistorical reality of a speaker or writer. Hence, in addition to various texts and utterances, narrative reminiscences as verbal expressions are always produced, organized, and understood in relation to various conventional forms. As frameworks for creating and interpreting meaning, genres provide shared schemes or interpretational outlines for communication. Thus, genres are located in interaction between individual and cultural means of expression, and writers and readers exploit them in order to produce and interpret discourse in a way that is relevant, sensible, and appropriate for them. Genres and intertextual links are loaded with meanings and values, and they convey significances in individual representations. Use of conventional forms mediates the meanings of earlier sayings, texts, sociohistorical contexts, and performances for others. Intertextuality is a creative discursive practice in which significances are produced between and through the relationship of utterances or generic conventions.

When analyzing intertextuality between "referential" narratives such as autobiographies, reminiscence writings, oral history, and genres of literature (including idylls and pastoral literature) as well as nostalgic representations in general, idealistic descriptions of the past should be taken neither as realistic depictions of the past nor as completely lacking referentiality to the reality that is being addressed. Indeed, nostalgic "referential" narratives should be understood through generic intertextuality 
as expressions or metaphors of writers' experiences, emotions, and attitudes, which are also linked to wider negotiations around the identity of the person and the community. The function of nostalgia in the case of Karelian evacuees is to express their positive goals and underline what is valued by them (see Wilson 2005:5-6), but at the same time it also refers to social changes and the destruction of the chain of generations connected to home places in Karelia. Nostalgic and ideal accounts of the lost home also point to the rhetorical power tied to generic intertextuality. By describing the original home place and the past there as something wonderful but unobtainable, writers also construct a narrative of a not-so-perfect present in a not-so-perfect place. In the case of Karelians, generic intertextual references to this juxtaposition highlight the magnitude of the sacrifice that Karelians made for the independence of Finland, and they underline the special status of Karelian evacuees compared to other Finns. Karelian evacuees are elevated as "chosen people" with a connection to the paradise lost, whereas the origins of other Finns are located in the not-so-perfect place that is still attainable in the present. Hence, in this case, generic intertextuality identifies evacuees as distinct from other Finns, and it supports claims for a greater acknowledgment of the loss of the evacuated Karelians, an acknowledgment that was not properly made after the war (see Kuusisto-Arponen 2009:546-7).

The reminiscence writings of child evacuees include descriptions of moments when a person's memories of a certain place encounter that same concrete place again. In that moment, writers describe that they can experience the past again and, in a sense, travel through time. Descriptions of journeys to Karelia not only illustrate spatial journeys that take place, but also temporal journeys. These descriptions reveal that journeys evoke a narrative reality in which the different moments in an individual's life merge together. In this dimension, the past and the present are in interaction with each other, and the negotiation between them can be called reminiscing. This negotiation is intertextual by nature, as writers use intertextuality in order to ponder relationships between the past and the present, as well as what could be described as mythical or fictional reality. From the viewpoint of reminiscing and the world of memory, these realities are not separate dimensions. Indeed, they are intertwined. I suggest that the creation of this kind of narrative reality in which the different moments of life come together according to a certain place also allows writers to reflect on their emotions and experiences concerning the past in order to incorporate them as an essential part of a narrative about their lives. This interconnectedness of the realities of personal experience and historical facts as well as the narrative conventions linked with them, I think, are the most important and characteristic features of life writings. However, this interconnectedness cannot be understood sufficiently if our conception of life writing or reminiscing is too strongly constrained by ideas of fact or fiction. I suggest that intertextual analysis could be one methodological tool to better reach beyond this oversimplified and meaning-reductive dichotomy that surely does not prevail in the actual world of these accounts or in the poetics of reminiscing.

The spatiotemporal distance from the Karelia of decades past has turned the Karelia of narratives and memories into a mythical, timeless, and idyllic place, a "site of memory" that has become a symbol of origin and roots. The nostalgic and idyllic idea of the lost Karelia has come to represent the unity of the generations that the lost 
place affirmed and defined. Individuals negotiate with this symbolic image, some supporting it and others countering it (see Halbwachs 1992:202-5; Lowenthal 1985:239). Journeys to Karelia create a new temporal layer for memories and narratives of place, which are merged together with the past; by refreshing memories, they can lead to a sense of "travelling through time." Thematic collections of writings about evacuation journeys also show that relationships with former home places in Karelia change through repeated journeys. Evacuees generate new experiences, new memories, and new sentiments of their home places. In addition, images and narratives of Karelia then and now merge as the region and its new inhabitants become familiar to the evacuees. This means that the place can become meaningful for writers as a concrete and contemporary place, not only as a place of memories that belongs to the past and therefore must be unchangeable. Furthermore, when evacuees write and share their narratives about their journey to home regions, such interactions develop into new kinds of poetic conventions.

I suggest that certain particulars of this article related to methodological and concrete aspects of intertextuality also apply to different genres of personal narrative, oral history, and life writing. Indeed, an intertextual reading of these kinds of narratives through the consideration of specific sociohistorical contexts can promote an understanding of the narrators' aims and messages beyond the thematic content of the narrative. This method of analysis underlines the nature of such narratives as creative expression, which is located deeply in the social and historical realm of each narrator.

\section{Acknowledgments}

I am grateful to the Finnish Cultural Foundation and the Academy of Finland project SA 294292 for funding my research. I also wish to express my gratitude to Dr. Karina Lukin for important remarks and to the anonymous JAF reviewers for insightful comments. For their helpful comments and suggestions, I would like to thank the editorial team of JAF. The archival materials discussed in this article come from the following collection: Children's Evacuation Journey collection LEM (Lasten evakkomatkat-keruu), Finnish Literature Society SKS (Suomalaisen Kirjallisuuden Seura), Folklore Archives KRA (Kansanrunousarkisto), 2004.

\section{Notes}

1. In the field of migration and diaspora studies there have been a range of discussions around the questions of place, home, displacement and belonging (e.g., Malkki 1995; Ahmed 1999; Basu 2005), identity, ethnicity, multiculturalism and transnationality (e.g., Appadurai 1996; Brah 1996; Mitchell 2004; Vertovec 2009), mobility (e.g., Clifford 1997; Cresswell 2006; Hannam, Sheller, and Urry 2006), experiences, emotions, and traumas (e.g., Baronian, Besser, and Jansen 2007; BenEzer 2006; McDowell 2005; Danforth 2003), as well as bodily, performative, aesthetic, and symbolic dimensions of movement (e.g., Duffy 2005; Basu 2006; Kuusisto-Arponen 2009).

2. The archival code used here (SKS. KRA. LEM. 2004) refers to Children's Evacuation Journey collection LEM (Lasten evakkomatkat-keruu), Finnish Literature Society SKS (Suomalaisen Kirjallisuuden Seura), Folklore Archives KRA (Kansanrunousarkisto), 2004, Helsinki, Finland.

3. Announcement, SKS. KRA. LEM. 2004.

4. "Jaakko" is a pseudonym; SKS. KRA. LEM. 2004:7-27. 
5. The parts written in Karelian dialect were translated into standard English by the author. The Karelian dialect mentioned in the context of my article refers to the southeastern dialect of the Finnish language, and it should not be confused with the language Karelian, which is spoken in the Russian Republic of Karelia and in Tver Karelia.

6. Kun sateenharmaa ilta alkoi jo hämärtyä ja meidän piti ehtiä vielä kirkonkylän Lokki-hotelliin majoittumaan ja ruokailemaan, saimme vain yhden tunnin ajan 'olla kotona'. Muodostui heti pikku ryhmiä, jotka suuntasivat kiireesti kohti omia kotipihojaan.

Meitä ol matkas kolme naapurusta ja lapsuuve leikkitoverii-Liisa, Aleksi ja mie-ko lähettii kiireest omal suunnal. Myö mäntii Naapuri Eetvarti piha läpi ja paja vierest Hankala kylätielle. Vähä vällii joku sano: 'Muistaks ko ... ?' ja sit haasteltii mitä siin kohas ol tapahtunt tai mihi se polku vei tai mitä muuta muisti toi mielee. Ja juttuu piisas, yks ko lopetti ni toine jatko muistelemist ja vanhoi tapahtummii oikee pulppus mielee.

Mitä lähemmäks kottii tultii sitä kovemmaks tul mei vauhti. Mäntii ohi Iitamari suon ja 'ristipetäjän' ja sit oltiikii jo meije entisel leikkikentäl Mairen ja miun kottii vieres. Pauli kottii ol viel vähä matkaa. Loppumatkan jo jokkaine juoks kotipihallee ja ko pihat olliit lähekkäi toisiaa, ni huuveltii sit ommii havaintoi toisillee.

Hankala kylä kaik rakennukset ol purettu iha perustuksiaa myöte, Kivijalkoi lisäks ol jälel ennää vaa kiviläävii ja-kellarii kiviset osat. Perustuksii sisäpuolel kasvo jo issoi puita. Pihat ol viel avonaiset. Vaa muutamii kuusetaimii kasvo meije pihal. Koivui ja leppii ol alkant kasvaa rantapellon oijii, mut pihalt näky merelahel melkee yhtä hyväst ko ennekkii.

Ko aikaa ol nyt vaa vähä ja piti keritä näkemää mahollisimma paljo, ni jätettii kotipihhoi tarkemp tutkimine seuraavaks päiväks ja myö mäntii Maire kans Pauli kottii. . . .

Äkkiää ol tunti mänt, mut sen aikanna ol nähty paljo ja viel enemmä ol tuntunt iha syväme pohjas ast. Tulla kotipihal mone kymmenä vuuve peräst on kyl semmone hetki, et se jääp kirkkaanna muistii koko loppuelämä ajaks. Se ol hetki mikä sai silmät kostumaaa ja mielen herkäks!

Vahvistamaton tieto kertoo, että saksalaiset sotavangit ovat purkaneet Revonsaaren rakennukset välittömästi sodan jälkeen. Mitään tietoa siitä, mihin rakennukset on siirretty, ei ole löytynyt (SKS. KRA. LEM. 2004:25).

7. Eiliset sadepilvet olivat häipyneet ja nyt paistoi aurinko, vain kevyet poutapilvet vaeltelivat sinisellä taivaalla. Tuntui kuin luontokin olisi varustautunut ottamaan meidät lämmöllä vastaan vuosikymmenien poissaolon jälkeen. . . . Istuuduin auringon paisteeseen kodin kivijalalle, suljin silmäni ja nostin ajatuksissani rakennukset pystyyn: Vuosikymmenet katosivat ja olin taas samanlaisella kotipihalla kuin ennen vanhaan!

Sit kokoonnuttii taas yhtee. Ko oltii siin mei entise leikkipaika lähel, ni miel sanoin, et männääs katsomaa meije korkeushyppypaikkaa. Ens mäntii seuraavii petäjii luo ja jopas tärppäs. Mie en kerint ko vähä silitellä männyn kaarnaa ko löysin yhen ruostuneen naulan. Siinhä se meije entine korkeushyppyteline olkii! Nyt se ruostunt ja vääntynt naula on miu palkintokaapis parraal paikal! . . Kyö tuo ihmise muisti on ihmeelline. Ko melkee viijekymmenä vuuve päästä vaelsin siel lapsuuve maisemis, ni niitä vanhan ajan muistikuvii tul mielee vaik kui paljo! (SKS. KRA. LEM. 2004:25-6).

8. Jo samana päivänä palattiin Viipurin ja Nuijamaan kautta takaisin Suomeen. Ajatuksissani liikuin kauan aikaa matkan jälkeen Revonsaaressa ja sieluni silmillä katselin saaren maisemia. Kun matkalla ottamani valokuvat sitten valmistuivat, kuljin niiden avulla moneen kertaan kotisaaressa vaeltamani reitit (SKS. KRA. LEM. 2004:26).

9. Toine maailmansota ol alkant. Miul jäi koko elämän pitune ikävä Kannakse kottii ja niihi varhaislapsuuve onne päivii. Se on vällee sitä mitä hyö sannoot taivasikäväks. Myö kaivataa takasii siihe paratiisii mist meijät on aikanaa ajettu pois jokahine. Se on se ihmise perusikävä ja tieto siit, et myö ollaa kotosii jostakii paljo paremmast-“ihanasta maasta”, niiko vanhas virres sanotaa (SKS. KRA. LEM. 2004:1593).

10. On mielestäni hyvä, että saaremme rakennukset on purettu eikä siellä ole asutusta. Jos koti olisi ränsistyneine rakennuksineen paikoillaan kuten mantereella ja kodissani asuisivat vieraat ihmiset, olisin käynyt siellä ehkä kerran. Mutta nyt on tilanne täysin toisenlainen. Nyt voi olla kotipihalla vapaasti kenenkään häiritsemättä, voi vaeltaa tutuissa maisemissa tuttuja teitä ja polkuja pitkin, voi antaa muistojen tulla aina näkymien myötä. Kylätietä kulkiessaan voi piipahtaa talojen pihoille, sulkea silmät ja ajatuksissaan 
kohottaa rakennukset ennalleen ja muistella talon entisiä asukkaita. Voi vaikka kuvitella millaista siellä olisi, jos sotia ei olisi ollut (SKS. KRA. LEM. 2004:27).

11. Olen todennut sekä itsestäni että myös muista kotimatkalaisista, että viha ja katkeruus vanhaa vainolaista kohtaan eivät ole matkoilla mukana. Olemme tajunneet, etteivät nykyiset Kannaksen asukkaat ole syypäitä meidän evakkouteemme. Kotiseutumatka on itselleni ollut eräänlainen pyhiinvaellusmatka, maisemien muistamisen vahvennusmatka ja lapsuusmuistojen mieleenpalauttamisen matka. Matkan tärkein osa alkaa siitä, kun Revonsaari ensi kerran vilahtaa näkyviin linja-auton ikkunasta ja päättyy siihen, kun saari viimeisen kerran häipyy paluumatkalla metsän taa.

Edellä kerrotun perusteella on varsin todennäköistä, että vielä kerran, jos Luoja elonpäiviä suo, olen jälleen evakosta palanneena poikana kotipihalla Revonsaaressa (SKS. KRA. LEM. 2004:27).

\section{References Cited}

Abrahams, Roger. 1993. Phantoms of Romantic Nationalism in Folkloristics. Journal of American Folklore 106(419):3-37.

Abrams, Lynn. 2010. Oral History Theory. London: Routledge.

Ahmed, Sara. 1999. Home and Away: Narratives of Migration and Estrangement. International Journal of Cultural Studies 2(3):329-47.

Alasuutari, Pertti, and Maarit Alasuutari. 2007. Second Generation Karelian Migrants: Narrating Belonging and Displacement. In On Foreign Ground: Moving between Countries and Categories, ed. Minna Ruckenstein and Marie-Louise Karttunen, pp. 89-101. Studia Fennica Anthropologica 1. Helsinki: Finnish Literature Society.

Allen, Graham. 2000. Intertextuality. London: Routledge.

Alpers, Paul. 1996. What Is Pastoral? Chicago: University of Chicago Press.

Appadurai, Arjun. 1996. Modernity at Large: Cultural Dimensions of Globalization. Minneapolis: University of Minnesota Press.

Armstrong, Karen. 2004. Remembering Karelia: A Family's Story of Displacement during and after the Finnish Wars. New York: Berghahn Books.

Bakhtin, Mikhail. 1981. The Dialogic Imagination: Four Essays by M. M. Bakhtin. Ed. Michael Holquist. Austin: University of Texas Press.

- 1986. Speech Genres and Other Late Essays. Ed. Caryl Emerson and Michael Holquist. Austin: University of Texas Press.

Bakhtin, Mikhail, and Pavel Medvedev. 1978. The Formal Method in Literary Scholarship: A Critical Introduction to Sociological Poetics. Cambridge, MA: Harvard University Press.

Bamberg, Michael. 2004. Considering Counter-Narratives. In Considering Counter-Narratives: Narrating, Resisting, Making Sense, ed. Michael Bamberg and Molly Andrews, pp. 351-71. Studies in Narrative 4. Amsterdam: John Benjamins Publishing.

- 2005. Positioning. In The Routledge Encyclopedia of Narrative Theory, ed. David Herman, Manfred Jahn, and Marie-Laure Ryan, pp. 445-6. New York: Routledge.

Baronian, Marie-Aude, Stephen Besser, and Yolande Jansen, eds. 2007. Diaspora and Memory: Figures of Displacement in Contemporary Literature, Arts, and Politics. Amsterdam: Rodopi.

Basso, Keith H. 1984. "Stalking with Stories": Names, Places, and Moral Narratives among the Western Apache. In Text, Play, and Story: The Construction and Reconstruction of Self and Society, ed. Stuart Plattner and Edward Bruner, pp. 19-55. Washington, DC: American Ethnological Society.

Basu, Paul. 2005. Macpherson Country: Genealogical Identities, Spatial Histories, and the Scottish Diasporic Clanscape. Cultural Geographies 12(2):123-50.

- 2006. Highland Homecoming: Genealogy and Heritage Tourism in the Scottish Diaspora. London: Routledge.

Bauman, Richard. 1986. Story, Performance, and Event: Contextual Studies of Oral Narrative. Cambridge Studies of Oral and Literate Culture 10. Cambridge: Cambridge University Press.

- 2004. World of Others' Words: Cross-Cultural Perspectives on Intertextuality. Oxford: Blackwell.

BenEzer, Gadi. 2004. Trauma Signals in Life Stories. In Trauma: Life Stories of Survivors, ed. Kim Lacy Rogers and Selma Leydesdorff, with Graham Dawson, pp. 29-44. Memory and Narrative. New Brunswick, NJ: Transaction Publishers. 
2006. The Migration Journey: The Ethiopian Jewish Exodus. Memory and Narrative. New Brunswick, NJ: Transaction Publishers.

Blom, Jan-Petter, and John J. Gumperz. 1972. Social Meaning in Linguistic Structures: Code-Switching in Norway. In Directions in Sociolinguistics: The Ethnography of Communication, ed. John Gumperz and Dell Hymes, pp. 407-34. New York: Holt, Rinehart, and Winston.

Boym, Svetlana. 2001. The Future of Nostalgia. New York: Basic Books.

Brah, Avtar. 1996. Cartographies of Diaspora: Contesting Indentities. London: Routledge.

Briggs, Charles L., and Richard Bauman. 1992. Genre, Intertextuality, and Social Power. Journal of Linguistic Anthropology 2(2):131-72.

Casey, Edward S. 1996. How to Get from Space to Place in a Fairly Short Stretch of Time: Phenomenological Prolegomena. In Senses of Place, ed. Steven Feld and Keith Basso, pp. 13-52. Santa Fe, NM: School of American Research Press.

Chase, Malcolm, and Christopher Shaw. 1989. The Dimensions of Nostalgia. In The Imagined Past: History and Nostalgia, ed. Christopher Shaw and Malcolm Chase, pp. 1-17. Manchester: Manchester University Press.

Clifford, James. 1997. Routes: Travel and Translation in the Late Twentieth Century. Cambridge, MA: Harvard University Press.

Connerton, Paul. 1989. How Societies Remember. Cambridge: Cambridge University Press.

Cresswell, Tim. 2006. On the Move: Mobility in the Modern Western World. London: Routledge.

Danforth, Loring M. 2003. "We Crossed a Lot of Borders": Refugee Children of the Greek Civil War. Diaspora 12(2):169-209.

Dolby, Sandra K. [1989] 2008. Literary Folkloristics and the Personal Narrative. Bloomington, IN: Trickster Press.

Dorst, John D. 1983. Neck-Riddle as a Dialogue of Genres: Applying Bakhtin's Genre Theory. Journal of American Folklore 96(382):413-33.

Duffy, Michelle. 2005. Performing Identity within a Multicultural Framework. Social and Cultural Geography 6(5):677-92.

Fingerroos, Outi. 2006. The Karelia of Memories-Utopias of a Place. Folklore: Electronic Journal of Folklore 33:95-108. http://www.folklore.ee/folklore/vol33/fingerroos.pdf.

— 2007. Uuskareliaanit nyky-Karjalassa. In Nykytulkintojen Karjala, ed. Outi Fingerroos and Jaana Loipponen, pp. 16-32. Nykykulttuurin tutkimuskeskuksen julkaisuja 91. Jyväskylä: University of Jyväskylä.

— 2008. Karelia: A Place of Memories and Utopias. Oral Tradition 23(2):235-54. http://journal .oraltradition.org/issues/23ii/fingerroos.

Finnish Karelian League. 2005. The Karelian Issue-Karelia Action Programm[e]. http://www .karjalanliitto.fi/files/315/karelian_issue.pdf.

Fowler, Alastair. 1982. Kinds of Literature: An Introduction to the Theory of Genres and Modes. Oxford: Clarendon.

Genette, Gérard. 1980. Narrative Discourse: An Essay in Method. Trans. Jane E. Lewin. Ithaca, NY: Cornell University Press.

Gifford, Terry. 1999. Pastoral: The New Critical Idiom. London: Routledge.

Glassie, Henry. 1982. Passing the Time in Ballymenone: Folklore and History of an Ulster Community. Philadelphia: University of Pennsylvania Press.

Goffman, Erving. 1981. Forms of Talk. Oxford: Blackwell.

Gumperz, John, and Eduardo Hernández-Chávez. 1972. Bilingualism, Bidialectalism, and Classroom Interaction. In Functions of Language in the Classroom, ed. Courtney B. Cazden, Vera P. John, and Dell Hymes, pp. 84-108. New York: Teachers College Press.

Hakamies, Pekka. 2005. New Culture on New Territories: The Karelian Isthmus and Ladoga Karelia in Post-War Years. In Moving in the USSR: Western Anomalies and Northern Wilderness, ed. Pekka Hakamies, pp. 91-109. Studia Fennica Historica 10. Helsinki: Finnish Literature Society.

Halbwachs, Maurice. 1992. On Collective Memory. Chicago: University of Chicago Press.

Hamilton, Paula. 2011. The Proust Effect: Oral History and the Senses. In Oxford Handbook of Oral History, ed. Donald A. Ritchie, pp. 219-32. New York: Oxford University Press.

Hanks, William F. 1987. Discourse Genres in a Theory of Practice. American Ethnologist 14(4):668-92. 
Hannam, Kevin, Mimi Sheller, and John Urry. 2006. Editorial: Mobilities, Immobilities, and Moorings. Mobilities 1(1):1-22.

Hastrup, Kirsten. 1987. Presenting the Past: Reflections on Myth and History. Folk: The Journal of the Danish Ethnographic Society 29:257-67.

Heimo, Anne. 2010. Kapina Sammatissa. Vuoden 1918 tulkinnat osana historian yhteiskunnallisen rakentamisen prosessia. Suomalaisen Kirjallisuuden Seuran Toimituksia 1275. Helsinki: Finnish Literature Society.

- 2016. Nordic-Baltic Oral History on the Move. Oral History 44(2):37-47.

Hill, Jane H., and Kenneth C. Hill. 1986. Speaking Mexicano: Dynamics of Syncretic Language in Central Mexico. Tucson: University of Arizona Press.

Hirsch, Marianne, and Leo Spitzer. 2007. Testimonial Objects: Memory, Gender, and Transmission. In Diaspora and Memory: Figures of Displacement in Contemporary Literature, Arts, and Politics, ed. Marie-Aude Baronian, Stephan Besser, and Yolande Jansen, pp. 137-63. Thamyris/Intersecting: Place, Sex, and Race 13. New York: Rodopi.

Huttunen, Laura. 2007. Between "the World” and a Pear Tree: Memory and Belonging in Bosnian Diaspora. In On Foreign Ground: Moving between Countries and Categories, ed. Minna Ruckenstein and MarieLouise Karttunen, pp. 174-87. Studia Fennica Anthropologica 1. Helsinki: Finnish Literature Society.

Jakobson, Roman. 1987. Language in Literature. Ed. Krystyna Pomorska and Stephen Rudy. Cambridge, MA: Belknap Press of Harvard University Press.

Kaarlenkaski, Taija. 2012. Kertomuksia lehmästä. Tutkimus ihmisen ja kotieläimen kulttuurisen suhteen rakentumisesta. Kultaneito IX. Joensuu: Suomen Kansantietouden Tutkijain Seura.

Kalliokoski, Jyrki. 1998. Hjalmar Nortamon murrekertomukset ja puhutun illuusio. In Sanan voima. Keskusteluja performatiivisuudesta, ed. Lea Laitinen and Lea Rojola, pp. 184-215. Tietolipas 160. Helsinki: Finnish Literature Society.

Kirshenblatt-Gimblett, Barbara. 1989. Authoring Lives. Journal of Folklore Research 26(2):123-49.

Kuusisto-Arponen, Anna-Kaisa. 2009. The Mobilities of Forced Displacement: Commemorating Karelian Evacuation in Finland. Social \& Cultural Geography 10(5):545-63.

Kuusisto-Arponen, Anna-Kaisa, and Ulla Savolainen. 2016. The Interplay of Memory and Matter: Narratives of Former Karelian Child Evacuees. Oral History 44(2):59-68.

Laine, Antti. 2005. Modernisation in the 1940s and 1950s in the Part of Karelia That Was Annexed from Finland on 13 March 1940. In Moving in the USSR: Western Anomalies and Northern Wilderness, ed. Pekka Hakamies, pp. 19-41. Studia Fennica Historica 10. Helsinki: Finnish Literature Society.

Laitinen, Lea. 1997. Kansan kieli: Kansallinen mieli. Virittäjä 101:279-88.

_ 1998. Dramaattinen preesens poeettisena tekona. In Sanan voima: Keskusteluja performatiivisuudesta, ed. Lea Laitinen and Lea Rojola, pp. 81-136. Tietolipas 160. Helsinki: Finnish Literature Society.

Latvala, Pauliina. 2005. Katse menneisyyteen: Folkloristinen tutkimus suvun muistitiedosta. Suomalaisen Kirjallisuuden Seuran Toimituksia 1024. Helsinki: Suomalaisen Kirjallisuuden Seura.

- 2014. "On Election Day the Husband Tied His Wife to a Table Leg to Stop Her from Voting": Political Narratives, Gender, and Archived Heritage in Finland. Folklore: Electronic Journal of Folkore 57:117-39. http://www.folklore.ee/folklore/vol57/latvala.pdf.

Lavery, Jason. 2006. The History of Finland. Westport, CT: Greenwood Press.

Lehto, Liisa, and Senni Timonen. 1993. Kertomus matkasta kotiin. Karjalaiset vieraina omilla maillaan. In Kauas on pitkä matka, ed. Pekka Laaksonen and Sirkka-Liisa Mettomäki, pp. 88-105. Kalevalaseuran vuosikirja 72. Helsinki: Finnish Literature Society.

Lowenthal, David. 1985. The Past Is a Foreign Country. Cambridge: Cambridge University Press.

Lury, Celia. 1997. The Objects of Travel. In Touring Cultures: Transformations of Travel and Theory, ed. Chris Rojekand and John Urry, pp. 75-95. London: Routledge.

Malkki, Liisa. 1995. Refugees and Exile. Annual Review of Anthropology 24:495-532.

McDowell, Linda. 2005. Hard Labour: The Forgotten Voices of Latvian Migrant Volunteer Workers. London: UCL Press.

Mikkola, Kati. 2009. Tulevaisuutta vastaan. Uutuuksien vastustus, kansantiedon keruu ja kansakunnan rakentaminen. Suomalaisen Kirjallisuuden Seuran Toimituksia 1251. Helsinki: Finnish Literature Society. 
Mitchell, Katharyne. 2004. Geographies of Identity: Multiculturalism Unplugged. Progress in Human Geography 28(5):641-51.

Myers-Scotton, Carol. 1993. Social Motivations for Codeswitching: Evidence from Africa. Oxford: Oxford University Press.

Niukko, Kirsi. 2009. The Concept of Landscape among Karelian Migrants in Finland. Journal of Borderlands Studies 24(2):62-77.

Ochs, Elinor, and Lisa Capps. 1996. Narrating the Self. Annual Review of Anthropology 25:19-43.

Paasi, Anssi. 1996. Territories, Boundaries, and Consciousness: The Changing Boundaries of the FinnishRussian Border. Chichester: John Wiley \& Sons.

Peltonen, Ulla-Maija. 1996. Punakapinan muistot: Tutkimus työväen muistelukerronnan muotoutumisesta vuoden 1918 jälkeen. Suomalaisen Kirjallisuuden Seuran Toimituksia 657. Helsinki: Finnish Literature Society.

— 2003. Muistin Paikat, Vuoden 1918 sisällissodan muistamisesta ja unohtamisesta. Suomalaisen Kirjallisuuden Seuran toimituksia 894. Helsinki: Finnish Literature Society.

Penfield, Joyce, and Jacob L. Ornstein-Galicia. 1985. Chicano English: An Ethnic Contact Dialect. Varieties of English around the World. General Series 7. Amsterdam: Johns Benjamins Publishing.

Penttilä, Aarni. 1945. Kirjailijat ja paikallismurre. Virittäjä 49:336-46.

Pink, Sarah. 2009. Doing Sensory Ethnography. Los Angeles: SAGE.

Portelli, Alessandro. 1997. The Battle of Valle Giulia: Oral History and the Art of Dialogue. Madison: University of Wisconsin Press.

Pöysä, Jyrki. 1997. Jätkän synty: Tutkimus sosiaalisen kategorian muotoutumisesta suomalaisessa kulttuurissa ja itä-suomalaisessa metsätyöperinteessä. Suomalaisen Kirjallisuuden Seuran Toimituksia 669. Helsinki: Finnish Literature Society.

2006. Kilpakirjoitukset muistitietotutkimuksessa. In Muistitietotutkimus. Metodologisia kysymyksiä, ed. Outi Fingerroos, Riina Haanpää, and Anne Heimo, pp. 221-44. Tietolipas 214. Helsinki: Finnish Literature Society.

Pöysä, Jyrki, and Senni Timonen. 2004. Kuinka ahkerat muurahaiset saivat kasvot? Henkilökohtaisen tiedon paikka arkiston keruuohjeissa. In Kansanrunousarkisto, lukijat ja tulkinnat, ed. Tuulikki Kurki, pp. 218-54. Suomalaisen Kirjallisuuden Seuran toimituksia 1002. Helsinki: Finnish Literature Society.

Richmond, W. Edson. 1961. The Study of Folklore in Finland. In Folklore Research around the World, ed. Richard M. Dorson, pp. 39-49. Bloomington: Indiana University Press.

Savolainen, Ulla. 2015. Muisteltu ja kirjoitettu evakkomatka: Tutkimus evakkolapsuuden muistelukerronnan poetiikasta. Kultaneito XV. Joensuu: Suomen Kansantietouden Tutkijain Seura.

— 2016. The Genre of Reminiscence Writings: Applying the Bakhtin Circle's Genre Theories. In Genre-Text-Interpretation: Multidisciplinary Perspectives on Folklore and Beyond, ed. Kaarina Koski and Frog, with Ulla Savolainen, pp. 203-31. Studia Fennica Folkloristica 22. Helsinki: Finnish Literature Society.

Schiller, Friedrich. 1800. On Nä̈ve and Sentimental Poetry. Part I. Trans. William F. Wertz, Jr. http:// schillerinstitute.org/transl/Schiller_essays/naive_sentimental-1.html.

Seitel, Peter. 2003. Theorizing Genres: Interpreting Works. New Literary History 34(2):275-97.

Sheridan, Dorothy. 1993. Writing to the Archive: Mass-Observation as Autobiography. Sociology: The Journal of the British Sociological Association 27(1):27-40.

Shuman, Amy. 2005. Other People's Stories: Entitlement Claims and the Critique of Empathy. Urbana: University of Illinois Press.

Sihvo, Hannes. [1973] 2003. Karjalan kuva: Karelianismin taustaa ja vaiheita autonomian aikana. Helsinki: Finnish Literature Society.

Siikala, Anna-Leena, and Jukka Siikala. 2005. Return to Culture: Oral Tradition and Society in the Southern Cook Islands. FF Communications No. 287. Helsinki: Academia Scientarum Fennica.

Tannock, Stuart. 1995. Nostalgia Critique. Cultural Studies 9(3):453-64.

Thompson, Stith. 1961. Folklore Trends in Scandinavia. In Folklore Research around the World, ed. Richard M. Dorson, pp. 27-34. Bloomington: Indiana University Press.

Toker, Leona. 1997. Toward a Poetics of Documentary Prose-From the Perspective of Gulag Testimonies. Poetics Today 18(2):187-222. 
Tonkin. Elizabeth. 1992. Narrating Our Pasts. Cambridge: Cambridge University Press.

Vertovec, Steven. 2009. Transnationalism. London: Routledge.

Waris, Heikki, Vieno Jyrkilä, Kyllikki Raitasuo, and Jouko Siipi. 1952. Siirtoväen sopeutuminen: Tutkimus Suomen karjalaisen siirtoväen sosiaalisesta sopeutumisesta. Helsinki: Otava.

Wernick, Andrew. 1997. Resort to Nostalgia: Mountains, Memories, and Myths of Time. In Buy This Book: Studies in Advertising and Consumption, ed. Mica Nava, Andrew Blake, Iain MacRury, and Barry Richards, pp. 207-23. New York: Routledge.

White, Hayden. 1987. The Content of the Form: Narrative Discourse and Historical Representation. Baltimore, MD: Johns Hopkins University Press.

Willman, Terhi. 2006. Urbanized Karelians. In Passages Westward, ed. Maria Lähteenmäki and Hanna Snellman, pp. 143-64. Studia Fennica Ethnologica 9. Helsinki: Finnish Literature Society.

Wilson, Janelle L. 2005. Nostalgia: Sanctuary of Meaning. Lewisburg, PA: Bucknell University Press.

Wolfson, Nessa. 1979. The Conversational Historical Present Alternation. Language 55(1):168-82. 


\section{PROJECT MUSE}

The Return: Intertextuality of the Reminiscing of Karelian

Evacuees in Finland

Ulla Savolainen

Journal of American Folklore, Volume 130, Number 516, Spring 2017, pp. 166-192 (Article)

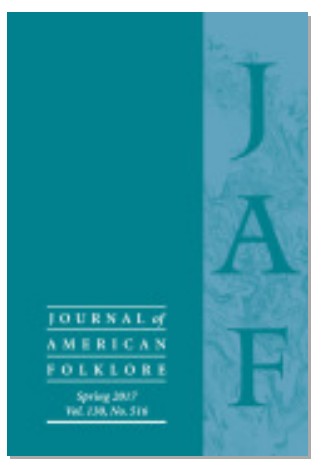

Published by American Folklore Society

$\Rightarrow$ For additional information about this article https://muse.jhu.edu/article/657564 